\title{
PENERAPAN RANTAI DINGIN SERTA SANITASI DAN HYGIENE UNTUK MENINGKATKAN KUALITAS HASIL TANGKAPAN NELAYAN DESA TAGALAYA
}

\section{APPLICATION OF COLD CHAIN, SANITATION AND HYGIENE TO IMPROVE THE QUALITY OF TAGALAYA FISHERMAN'S CATCH}

\author{
Febrina Olivia Akerina ${ }^{1)^{*}}$, Femsy Kour ${ }^{2)}$ \\ ${ }^{1)}$ Fakultas Sains, Teknologi dan Kesehatan, Universitas Hein Namotemo, Tobelo \\ email: feraakerina@gmail.com \\ ${ }^{2)}$ Fakultas Sains, Teknologi dan Kesehatan, Universitas Hein Namotemo, Tobelo \\ email: kourfemsy87@gmail.com
}

\begin{abstract}
ABSTRAK
Desa Tagalaya merupakan salah satu Desa di Kecamatan Tobelo yang masyarakatnya bermata pencaharian sebagai nelayan. Cara penangkapan menggunakan alat tangkap sederhana dan armada penangkapanpun masih tradisional, dengan demikian proses penanganan, sanitasi dan hygiene belum dilakukan secara efektif dan efisien. Secara umum, masyarakat desa Tagalaya tidak menggunakan es karena lokasi penangkapan ikan dan penjualan dekat. Kegiatan ini bertujuan untuk meningkatkan pengetahuan nelayan mengenai pentingnya penerapan rantai dingin (Cold Chain System) serta sanitasi dan hygiene, sehingga nilai jual hasil tangkapan tinggi dan berkualitas baik. Metode pelaksanaan kegiatan pengabdian adalah melalui kegiatan penyuluhan dan diskusi. Penyampaian materi mengenai sistem rantai dingin meliputi konsep rantai dingin, dampak tidak diterapkannya rantai dingin terhadap hasil tangkapan. Sedangkan cakupan materi mengenai sanitasi dan hygiene hasil tangkapan adalah pengertian dan ruang lingkup sanitasi dan hygiene serta dampak penerapan sanitasi dan hygiene. Hasil kegiatan yakni masyarakat antusias menerima kateri yang disampaikan, beberapa diantara mereka berkomitmen untuk menerapkan materi yang didapat untuk meningkatkan nilai jual hasil tangkapan.
\end{abstract}

Kata kunci: Desa Tagalaya, Rantai dingin, Sanitasi dan hygiene, Penanganan ikan

\begin{abstract}
Tagalaya is one of the Village in Tobelo sub-district whom its inhibitants did fisheries for living. Their fishing method were simple and conventional, also their handling method, sanitation and hygiene practice were not effective and efficient. Commonly, Tagalaya inhibitants are not using ice for initial handling because fishing areas and selling location nearby. The aim of this activity was to increase the fisheries knowledge about the importance of cold chain system, sanitanion and hygiene of their catches, it can affect its selling price and quality. This activity was carried out in form of counseling and discussion. The theory about cold chain system and its impact if it cannot applied; the scope of sanitation and hygene and its positive impact were delivered. The result of this activity was the fisheries are very enthusiastic and commited to apply the theory in their fishing activity (fishing handling) to increase fish selling price.
\end{abstract}

Keywords: Tagalaya, Cold Chain, Sanitation and Hygiene, Fish handling

\section{PENDAHULUAN}

Desa Tagalaya merupakan salah satu

Desa di Kecamatan Tobelo yang sebagian besar warga desanya bermata pencaharian sebagai nelayan [1] dan dilakukan secara turun temurun. Cara penangkapan menggunakan alat tangkap yang sederhana yakni pancing tangan dan panah, yang 
dilakukan oleh kaum pria dan hasil tangkapannya dijual oleh kaum wanita. Armada penangkapan yang digunakan adalah perahu yang masih tradisional [1] sehingga proses penanganan, sanitasi dan hygiene belum dilakukan secara efektif dan efisien.

Tingkat kesegaran ikan dipengaruhi oleh penanganan awal yang dilakukan sesaat setelah ikan ditangkap. Kesegaran ikan berperan penting dalam menentukan mutu suatu produk hasil perikanan diantaranya saat proses produksi dan menentukan harga jual ikan [2]. Penanganan merupakan cara yang umum digunakan, sehingga perlu dilakukan dengan baik dan benar, sehingga dapat mempertahankan kesegaran ikan [3]. Penanganan dilakukan dengan mempertahanakan suhu ikan tetap rendah dengan menerapkan sistem rantai dingin dan sanitasi dan hygiene.

Penerapan sistem rantai dingin dilakukan dengan menggunakan media pendingin yakni Es. Es dipilih karena harganya relative mudah, tidak mengandung bahan berbahaya, serta cara penggunaannya mudah [2]. Selain itu, es juga dapat menghambat pertumbuhan mikroorganisme yang dapat menyebabkan kebusukan ikan.

Pengetahuan tentang pentingnya es masih belum dipahami oleh masyarakat desa Tagalaya, karena sebagian besar nelayan tidak menggunakan es untuk mempertahankan kesegaran ikan, karena waktu penangkapan singkat ( \pm 7 jam $)$ dan lokasi penjualan ikan tidak jauh dari daerah penangkapan ikan. kuranya pengetahuan nelayan mengenai rantai dingin serta sanitasi dan hygiene ini menyebabkan kualitas ikan hasil tangkapan menurun dan berpengaruh pada harga jual. Dengan demikian perlu dilakukan kegiatan penyuluhan/ sosialisasi terkait masalah yang dihadapi.

Kegiatan ini bertujuan untuk meningkatkan pengetahuan kepada nelayan di Desa Tagalaya mengenai pentingnya penerapan rantai dingin (Cold Chain System) serta sanitasi dan hygiene, sehingga nilai jual hasil tangkapan tinggi dan memiliki kualitas yang baik hingga ke tangan konsumen. Berdasarakan uraian di atas, maka dilakukan kegiatan pengabdian kepada masyarakat bagi nelayan di Desa Tagalaya.

\section{METODE PELAKSANAAN}

Kegiatan pengabdian ini merupakan program Desa tagalaya, sehingga kami melakukan koordinasi dengan kepala Desa dan perangkat desa untuk mempersiapkan kegiatan hingga akhir kegiatan.

Metode pelaksanaan kegiatan pengabdian ini berupa penyampaian materi melalui kegiatan penyuluhan dilanjutkan dengan diskusi. Penyampaian materi menggunakan LCD proyektor, sehingga dapat ditunjukkan video dan gambar- 
gambar berkaitan dengan materi yang disampaikan.

Kegiatan penyuluhan perikanan merupakan proses pembelajaran bagi pelaku utama dan pelaku usaha perikanan serta keluargannya untuk meningkatan potensi dan kemampuannya sehingga dapat mengatasi kebutuhan dan keinginannya tanpa bergantung pada orang lain [4].

\section{HASIL DAN PEMBAHASAN}

Kegiatan pengabdian kepada masyarakat dilaksanakan di Kantor Desa Tagalaya, Kecamatan Tobelo, Kabupaten Halmahera Utara, dan dihadiri oleh 30 orang peserta yang terdiri dari nelayan dan perangkat desa Tagalaya. Kegiatan diawali dengan pembukaan oleh Kepala Desa Tagalaya dan Doa, dan dilanjutkan dengan penyampaian materi oleh narasumber. Pembukaan kegiatan dapat dilihat pada Gambar 1.

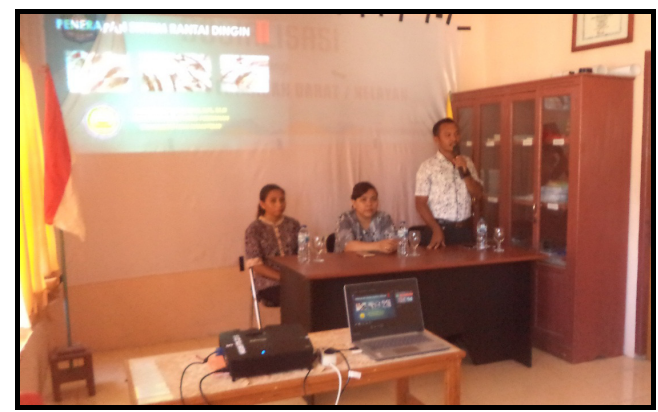

(a)

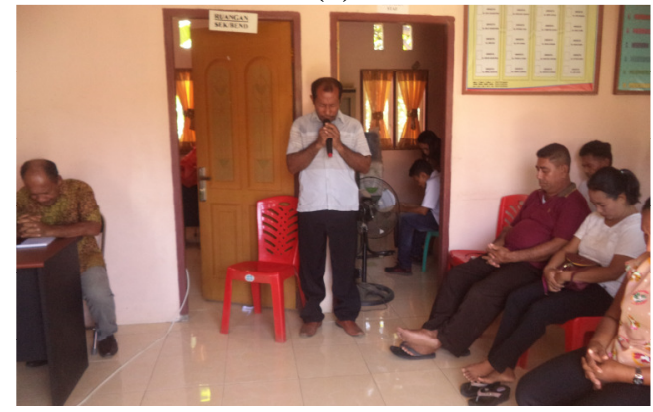

(b)
Gambar 1. (a) pembukaan oleh kepala

Desa; (b) Doa dipimpin oleh salah satu perangkat Desa

Materi yang disampaikan dalam kegiatan ini antara lain penerapan sistem rantai dingin serta sanitasi dan hygiene hasil tangkapan nelayan. Penyampaian materi oleh 2 dilihat pada Gambar 2.

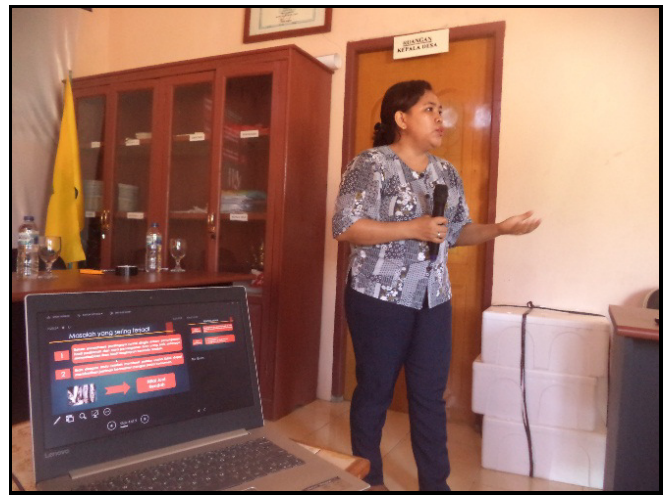

(a)

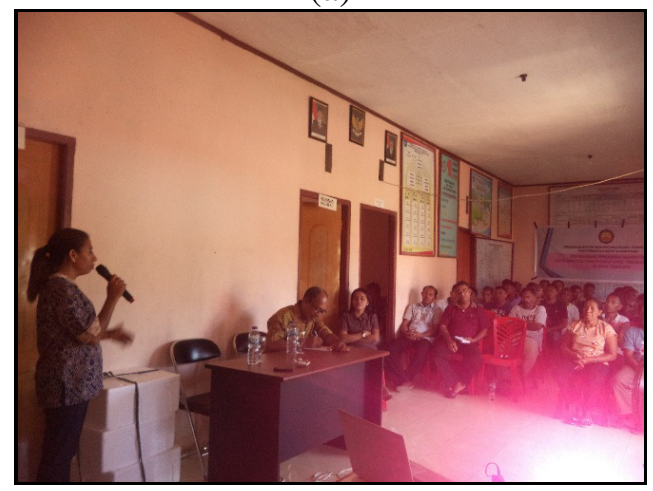

(b)

Gambar 2. (a) Penyampaian materi penerapan sanitasi dan Hygiene; (b) Penyampaian materi sanitasi dan hygiene hasil tangkapan

\section{Penerapan Rantai Dingin (Cold Chain System)}

Penyampaian materi mengenai sistem rantai dingin akan memberikan pemahaman kepada nelayan, mengenai pentingnya menjaga ikan dalam kondisi yang masih segar sesaat setelah ditangkap dan sampai ke tangan konsumen. Cakupan materi yang disampaikan adalah konsep mengenai rantai dingin, permasalahan yang terjadi akibat 
tidak diterapkannya rantai dingin saat penangkapan serta metode pendinginan yang efektif dan efisien.

Sistem rantai dingin (cold chain system) merupakan sistem yang bertujuan untuk menjamin keseluruhan proses dari pasca panen (penangkapan), distribusi dan sampai ditangan konsumen dalam kondisi segar dengan cara menerapkan suhu mendekati $0{ }^{\circ} \mathrm{C}$ [5]. Selain itu, menurut [6] sistem rantai dingin diartikan sebagai sebuah sistem yang menjaga produk baik beku atau dingin dalam kondisi (suhu) tertentu selama produksi, penyimpanan, transportasi, dan penjualan, dengan tujuan menjaga kualitas produk.

Penerapan rantai dingin belum dipahami oleh nelayan salah satunya nelayan desa Tagalaya. Berdasarkan hasil survei awal, secara umum, nelayan desa Tagalaya tidak menggunakan es sebagai media pendingin, karena lokasi penangkapan dengan tempat penjualan ikan tidak jauh, selain itu waktu penangkapan yang singkat menjadi alasan tidak digunakannya es. Hal ini menandakan bahwa pengetahuan tentang pentingnya rantai dingin tidak dipahami oleh masyarakat.

Menurunnya nilai ikan berhubungan dengan fungsi waktu, sehingga penerapan sistem rantai dingin harus diawali setelah ikan ditangkap (saat disimpan di perahu) dengan tujuan menjaga ikan tetap segar. Pada akhirnya, kesegaran ikan akan berpengaruh pada nilai jual ikan di pasaran. Ikan akan memiliki nilai jual tinggi saat tingkat kesegarannya juga tinggi [7].

Selain itu, pada kegiatan pengabdian, juga disampaikan mengenai cara-cara pendinginan yang efektif dan mudah yang dapat diterapkan oleh nelayan di Desa Tagalaya. Pendinginan yang efektif dapat menggunakan es dan air dingin (Es ditambah dengan air).

Teknik pendinginan dengan menggunakan Es dapat menurunkan suhu pusat daging ikan pada -1 sampai $-2^{\circ} \mathrm{C}$ yang ditujukan untuk memasarkan ikan dalam keadaan basah. Es berfungsi untuk mempertahankan ikan dalam kondisi yang segar, mencegah proses pembusukan oleh bakteri sehingga dapat mempertahankan nilai gizi ikan. Selain itu, es yang meleleh juga dapat mencuci lendir, darah dan kotoran lain [8]

\section{Sanitasi dan Hygiene Hasil Tangkapan}

Materi mengenai sanitasi dan hygiene hasil tangkapan memberikan pemahana kepada nelayan mengenai pentingnya penerapan sanitasi dan hygiene baik pada armada penangkapan maupun pasca penangkapan ikan. Penyampaian materi mengenai sanitasi dan hygiene hasil tangkapan meliputi : pengertian serta ruang lingkup sanitasi dan hygiene, serta dampak penerapan sanitasi dan hygiene.

Secara umum, sanitasi dan hygiene merupakan istilah yang tidak lazim di masyarakat, sehingga penerapannya pun 
belum diketahui. Pentingnya sanitasi dan hygiene perlu dipahami oleh masyarakat karena berhubungan dengan mutu hasil tangkapan. Penerapan sanitasi dan hygiene yang disampaikan pada kegiatan penyuluhan ini terdiri atas kebersihan diri (nelayan), armada dan alat penangkapan, serta kebersihan alat penanganan hasil tangkapan. Sanitasi dan hygiene memiliki arti yang berbeda, menurut [9] sanitasi berhubungan dengan mengurangi pengaruh lingkungan terhadap dampak penyakit yang dapat ditimbulkan, dalam hal ini mengurangi resiko rusaknya/menurunnya mutu hasil tangkapan akibat lingkungan tidak bersih (armada dan alat penangkapan, serta alat penanganan), sedangkan hygiene berhubungan erat dengan kebersihan perorangan dalam hal ini nelayan. Dalam kegiatan penangkapan ikan, selain lingkungan, kesehatan perorangan juga berpengaruh. Kesehatan dan kebersihan diri perlu dijaga untuk menghindari kontaminasi, sehingga akan mempengaruhi mutu hasil tangkapan sehingga aman dikonsumsi oleh konsumen.

\section{KESIMPULAN}

a) Penyuluhan mengenai penerapan rantai dingin meningkatkan pengetahuan masyarakat mengenai pentingnya rantai dingin dalam menjaga kualitas hasil tangkapan serta teknik pendinginan yang efektif dan efisien.

b) Penyampaian materi mengenai sanitasi dan hygiene membantu masyarakat dalam meningkatkan kebersihan diri, armada penangkapan serta hasil tangkapan untuk mengurangi resiko kontaminasi yang akan mempengaruhi kualitas hasil tangkapan.

\section{SARAN}

Disarankan untuk dapat memberikan penyuluhan mengenai diversifikasi produk perikanan kepada ibu-ibu rumah tangga, karena berdasarkan hasil survei, seluruh hasil tangkapan dijual tanpa ada pengolahan.

\section{UCAPAN TERIMAKASIH}

Ucapan terima kasih disampaikan kepada :

a) Kepala Desa, perangkat Desa serta seluruh masyarakat Tagalaya yang telah memberikan izin kepada tim pengabdian kepada masyarakat untuk memberikan penyuluhan

b) Kepada Kepala LPPM Universitas Hein Namotemo yang telah mendukung dalam memberikan rekomendasi dan menugaskan tim melakukan pengabdian.

\section{REFERENSI}

[1] BPS. 2018. Dalam Angka. Kota Kediri Dalam Angka. hal. 1-68

[2] Wiranata, K. Widia, K.I.W and Sanjaya, I. P. G. B. 2017. Pengembangan Sistem Rantai Dingin Ikan Tongkol (Euthynnus Affini) Segar untuk Pedagang Ikan Keliling. BETA (Biosistem dan Tek. Pertanian). 6(1):12-21

[3] Metusalach, Kasmiati, Fahrul, and I. Jaya. 2014. Effect of Fishing Techniques, Handling Facilities and Methods on Quality of the Fish. J. 
IPTEKS PSP. 1(1):40-52

[4] Ranum, G. A. R. 2018. Komunikasi Penyuluhan pada Pengelolaan Sumberdaya Perikanan Berbasis Kearifan Lokal. J. Penyul. Perikan. dan Kelautan. 12(2):129-147

[5] Sufiah, W. O. Sarini, Y. and Lawelle, S. A. 2017. Sistem Rantai Dingin Rajungan (Portunus pelagicus) (Studi Kasus UD. Irfandi di Desa Lakara, Kecamatan Palangga Selatan, Kabupaten Konawe Selatan. Sos. Ekon. Perikan. FPIK UHO. 2(3):143-150.

[6] Zhu, X. Zhang, R. Chu, F. He, Z.and $\mathrm{Li}, \quad$ J. 2014. A Flexsim-Based Optimization for the Operation Process of Cold-Chain Logistics Distribution Centre. J. Appl. Res.
Technol. 12(2):270-278

[7] Aminatuzzuhra, R. Purwaningsih, Susanto, N. 2016. Simulasi Cold Chain System pada Rantai Distribusi Ikan untuk Mengukur Peningkatan Mutu Ikan di Kota Semarang. Indusrial Engineering Online Journal 5(4):1-12

[8] Sanger, G. 2010. Mutu Kesegaran Ikan Tongkol (Auxis tazard) selama Penyimpanan Dingin. War. Wiptek. 1(35):39

[9] Domili R. S. dan Febriyanti, T. L. . 2018. Kajian Sanitasi dan Hygienen pada Pengasapan Ikan Julung-Julung (Sagela) di Desa Pasalae Kecamatan Gantum Raya Kebupaten Gorontalo Utara. Akademia. 7(1):44-50 